Fitriah; Tanggung Jawab Produk Dalam Transaksi E-Commerce, Halaman 118-125

\title{
TANGGUNG JAWAB PRODUK DALAM TRANSAKSI E-COMMERCE
}

\author{
Fitriah \\ Fakultas Hukum Universitas Palembang \\ E-mail: fitriahsyahrial@g mail.com
}

\begin{abstract}
Product responsibility in e-commerce transactions is the civil responsibility of business actors for losses suffered by consumers due to using the products they produce, the presumption of liability principle as a modification of the principle of responsibility on the reverse burden of proof. The principle of absolute responsibility adopted by producers gives very important attention to producers in protecting consumers as the weak party in carrying out a transaction, especially in e-commerce transactions. Product liability that adheres to stict liability can be very useful for consumers in protecting consumers in e-commerce transactions. So that consumers are not obliged to prove a mistake, it's just that consumers in a transaction should be able to prove that a product they use is defective so that it is detrimental to it.
\end{abstract}

Keywords: Product Responsibility; E-Commerce

\begin{abstract}
Abstrak
Tanggung Jawab Produk dalam transaksi e-commerce sebagai tanggung jawab perdata dari pelaku usaha atas kerugian yang dialami konsumen akibat menggunakan produk yang dihasilkannya, prinsip praduga untuk selalu bertanggung jawab (presumption of liability principle) sebagai salah satu modifikasi dari prinsip tanggung jawab pada beban pembuktian terbalik. Prinsip tanggungjawab mutlak yang dianut oleh para produsen memberikan perhatian yang sangat penting bagi para produsen dalam melindungi konsumen selaku pihak yang lemah dalam menjalankan suatu transaksi, terutama dalam transaksi e-commerce. Product liability yang menganut stict liability dapat sangat berguna bagi para konsumen dalam melindungi para konsumen dalam transaksi e-commerce. Sehingga konsumen tidak berkewajiban membuktikan suatu kesalahan, hanya saja para konsumen dalam bertransaksi hendaknya dapat membuktikan kalau suatu produk yang dipakainya cacat sehingga merugikannya.
\end{abstract}

Kata Kunci: Tanggung Jawab Produk; E-Commerce

\section{PENDAHULUAN}

Penggunaan internet menjadi

salah satu agenda penting dalam masyarakat, hadirnya internet dapat digunakan dalam segala aktivitas kehidupan sehari-hari. Hal inilah yang menjadikan informasi sebagai komoditas ekonomi yang berguna serta dapat menguntungkan bagi masyarakat, karena dengan internet konsumen dapat melakukan transaksi di manapun mereka berada, hal inilah yang dapat mempermudah semua perdagangan. ${ }^{1}$

Era globalisasi telah memudahkan kegiatan bisnis melalui perkembangan teknologi dan komunikasi. Salah satu perkembangan yang signifikan sekarang adalah transaksi jual beli secara online atau $e$ -

\footnotetext{
${ }^{1}$ Agus Raharjo. Cybercrime: Pemahaman dan Upaya Pencegahan Kejahatan Berteknologi (Bandung: PT. Citra Aditya Bakti, 2002).
} 
Fitriah; Tanggung Jawab Produk Dalam Transaksi E-Commerce, Halaman 118-125

commerce. Orang semakin mudah berhubungan dengan orang lain. Penjual dan pembeli tidak perlu bertatap muka (face to face) untuk melakukan transaksi jual beli, melainkan hanya perlu memiliki koneksi internet yang akan mempertemukan mereka di dunia virtual. $^{2}$

Dalam transaksi e-commerce yang merupakan transaksi perdagangan digital mempunyai jaringan yang terbuka. Jadi hal inilah dapat berakibat atau mempunyai akibat baik dari segi positif maupun negatif. Untuk segi positifnya dapat meningkatkan pelayanan, sehingga perdagangan dapat dengan mudah dan efisen dilakukan. Sedangan dari segi negatifnya berkaitan dengan adanya kepastian hukum, karena penggunaan perdagangan dengan e-commerce ini keamanannya masih belum bisa dipastikan.

Dalam hukum tanggungjawab suatu produk, dimana dalam hal ini dikaitkan dengan adanya kepastian hukum, maka hukum tanggungjawab produk merupakan

2 Ardiana Hidayah. "Konsep Pembangunan Hukum E-Commerce." http://jurnal.unpal.ac.id/index.php/solusi/article /view/168/134, Solusi, Volume 17 Nomor 2. Bulan Mei (2019): 107 jaminan bagi para konsumen dalam hal untuk mendapatkan suatu keamanan, kesehatan dan keselamatan untuk para konsumen dalam melakukan transaksi perdagangan dan melindungi hak-hak para konsumen dari kerugian. Di bidang produksi (equality control techniques), instrument ini sangat diperlukan, karena dalam perdagangan barang dapat mencegah dan melindungi para konsumen serta menghindari kerugian yang dapat berupa kerusakan ataupun adanya cacat tersembunyi (bodily/personal injur), dan kerusakan pada suatu produk.

Adanya suatu peraturan mengenai cara berproduksi dalam suatu produksi, yang mana hal ini sangat dibutuhkan demi terjaminnya suatu ganti kerugian akibat konsumen memakai atau mengkonsumsi produk yang dihasilkan, atau istilah lainnya dikenal dengan hukum tanggung jawab produk (product liability). ${ }^{3}$ Hal ini terdapat dalam Pasal 19 UUPK, antara lain :

1. Para pelaku usaha bertanggungjawab dalam memberikan ganti kerrugian dari kerusakan, pencemaran dan/atau kerugian para konsumen yang memakai barang dan atau jasa tersebut.

3 Zulham. Hukum Perlindungan Konsumen (Jakarta: Kencana Penada Media Group). 
Fitriah; Tanggung Jawab Produk Dalam Transaksi E-Commerce, Halaman 118-125

2. Dalam hal ganti kerugian tersebut, harus sesuai dengan ketentuan perundang-undangan yang berlaku.

3. Tenggang waktu yang diberikan tujuh hari setelah transaksi berlangsung.

4. Ganti rugi tidak menghapus tindak pidana dengan berdasarkan pembuktian lebih lanjut terhadap adanya unsure kesalahan.

5. Ketentuan ayat (1) dan (2), tidak berlaku selama pelaku usaha dapat membuktikannya.

Dalam hal ini, Tanggung Jawab Produk (Product Liability), merupakan tanggung jawab perdata dari pelaku usaha atas kerugian yang dialami konsumen akibat menggunakan produk yang dihasilkannya. Di sini juga para pelaku usaha bertanggung jawab untuk memberikan ganti rugi atas: a. Kerusakan; b. Pencemaran; dan c. Kerugian konsumen akibat mengkonsumsi barang yang dihasilkan atau diperdagangkan.

Istilah consumer (Inggris) , diartikan dalam kamus yaitu sebagai seorang atau sesuatu perusahaan dalam membeli suatu batang tertentu dan juga dalam menggunakan jasa tertentu, atau seseorang yang juga menggunakan sejumlah barang atau juga jasa. ${ }^{4}$

Sering kali muncul istilah seorang pembeli adalah raja, tapi sering kali juga kita mendengar atau membaca serta menyuarakan atau memuat cerita tentang kemarahan atau akibat kekecewaan para konsumen terhadap pemakaian sebuah produk yang dihasilkan oleh pelaku usaha yang semaunya, tapi sering juga para konsumen tetap berada di pihak yang lemah. Tapi sejak tanggal 20 April 1999, konsumen telah memperoleh perlindungan yang lebih layak serta telah memiliki posisi seimbang dengan produsen, sebagaimana telah diatur dalam Undang-undang Nomor 8 Tahun 1999 tentang Hukum Perlindungan Konsumen.

$\begin{array}{llr}\text { Dari } & \text { latar } & \text { belakang diatas } \\ \text { penulis } & \text { ingin } & \text { mengangkat }\end{array}$
permasalahan tentang perkembangan prinsip tanggung jawab produk dalam transaksi e-commerce ditinjau dari hukum perlindungan konsumen.

\section{PEMBAHASAN}

Berdasarkan sejarah perkembangannya, awal mula suatu

${ }^{4}$ Jhon M Echols dan Hasan Sadly. Kamus Inggris-Indonesia (Jakarta: Balai Pustaka, 1995). 
Fitriah; Tanggung Jawab Produk Dalam Transaksi E-Commerce, Halaman 118-125

produk mulai diperkenalkan tentang prinsip dasar suatu tanggungjawab produk, hingga sampai puncaknya dimana dalam perjanjian jual beli suatu produk terdapat suatu peraturan yang dikeluarkan oleh Kaisar Justinianus sesudah masehi sekitar tahun 533, dimana penjualan produk mulai bertanggungjawab. Hal ini agar tidak terjadi suatu kesalahan dalam menghasilakan suatu produk dan memperkecil suatu kerugian yang dapat ditimbulkannya. Terdapat tiga perilaku pelaku usaha yang digolongkan sebagai kejahatan, yaitu kelalaian dalam memberikan pelayanan terhadap para pembeli (konsumen), tidak mengungkapkan cacat tersembunyi dari suatu barang atau produk yang dijual, serta menjual suatu produk yang tidak memenuhi standar sesuai yang dijanjikan. Hal inilah ditetapkan sebagai suatu standar yang cukup keras bagi para pelaku usaha dan digolongkan sebagai suatu kejahatan.

Sebagai dasar suatu tuntutan atas tanggungjawab suatu produk, terhadap konsumen yang merasa dirugikan, yaitu tuntutan karena suatu kelalaian, tuntutan karena adanya suatu wanprestasi/ingkar janji, dan tuntutan berdasarkan atau menurut teori tanggung jawab mutlak (strict product liability). Dalam substansi hukum perlindungan konsumen yang mengalami perkembangan dan perubahan dari hukum yang berkarakteristik represif dalam bentuk prinsip tanggung jawab berdasarkan kesalahan (fault based liability) keprinsip tanggung jawab yang berpihak atau responsif terhadap kepentingan konsumen dalam bentuk prinsip tanggung jawab mutlak (strict product liability). ${ }^{5}$

Prinsip tanggung jawab bagi pelaku usaha atas kerugian yang dialami oleh para konsumen di Indonesia dalam Undang-undang Nomor 8 Tahun 1999 Tentang Perlindungan Konsumen (UUPK). Lemahnya posisi konsumen ini mengakibatkan konsumen kesusahan dalam menuntut haknya kepada pelaku usaha. ${ }^{6}$ Pada Pasal 19 mengatur pertanggungjawaban bagi para pelaku usaha baik pabrik dan/atau distributor

5 Soemardjono Brodjo Soedjon. "Hukum Perlindungan Konsumen dalam Transaksi Konsumen di Dunia Maya tentang Tanggung Jawab

Produk.'https://media.neliti.com/media/publica tions/220778-hukum-perlindungan-konsumendalam-transa.pdf

6 Husni Ayawali, Neni Sri Imaniyati (ed) Hukum Perlindungan Konsumen. (Bandung: Mandar Maju, 2000). 
Fitriah; Tanggung Jawab Produk Dalam Transaksi E-Commerce, Halaman 118-125

pada umumnya, untuk memberikan ganti rugi atas kerusakan, pencemaran, dan/atau kerugian konsumen akibat mengkonsumsi barang dan/atau jasa yang dihasilkan atau diperdagangkan, dengan ketentuan bahwa biaya ganti rugi tersebut dapat dilakukan dalam bentuk: pengembalian uang atau penggantian barang dan/atau jasa yang sejenis atau setara nilainya, atau perawatan kesehatan dan/atau pemberian santunan yang sesuai dengan ketentuan peraturan perundangundangan yang berlaku. Ganti rugi harus telah diberikan dalam jangka waktu 7 (tujuh) hari terhitung sejak tanggal transaksi. Pasal 20 diberlakukan bagi pelaku usaha periklanan untuk bertanggung jawab atas iklan yang diproduksi, dan segala akibat yang ditimbulkan oleh iklan. Pasal 21 ayat (1) membebankan pertanggungjawaban kepada importir barang sebagai mana layaknya pembuat barang yang diimpor, apabila importasi barang. tersebut tidak dilakukan oleh agen atau perwakilan produsen luar negeri. Pasal 21 ayat (2) mewajibkan importir jasa untuk bertanggung jawab sebagai penyedia jasa asing, jika penyediaan jasa asing tersebut tidak dilakukan oleh agen atau perwakilan penyedia jasa asing. Pasal 24 yang mengatur peralihan tanggung jawab dari satu pelaku usaha kepada pelaku usaha lainnya.

Dalam UUPK terdapat 2 (dua) Pasal yang menggambarkan sistem tanggung jawab produk dalam hukum perlindungan konsumen di Indonesia, yaitu ketentuan Pasal 19, Pasal 23 UUPK. Pada rumusan Pasal 23 UUPK nampaknya muncul berdasarkan Pasal 19 UUPK menganut prinsip praduga lalai/bersalah (presumption of negligence). Pada prinsip ini berangkat apabila produsen tidak melakukan kesalahan, maka konsumen tidak mengalami kerugian jadi berarti produsen telah melakukan kesalahan.

Dasar pemikiran dari Teori Pembalikan Beban Pembuktian adalah seseorang dianggap bersalah, sampai yang bersangkutan dapat membukti kan sebaliknya. Asas ini cukup memberikan perlindungan bagi konsumen. $^{7}$

Penerapan Prinsip Tanggung Jawab Mutlak dalam Hukum Tanggung Jawab Produk. Dalam product liability, pihak konsumen yang akan menuntut

${ }^{7}$ Tami Rusli. "Tanggung Jawab Produk Dalam Hukum Perlindungan Konsumen." https://media.neliti.com/media/publications/26 769-ID-tanggung-jawab-produk-dalam-hukumperlindungan-konsumen.pdf, Jurnal Pranata Hokum, Volume 7 Nomor 1 Januari 2012. 
Fitriah; Tanggung Jawab Produk Dalam Transaksi E-Commerce, Halaman 118-125

kompensasi didasarkan : pertama, bahwa produk tersebut telah cacat pada saat waktu diserahkan oleh produsen; kedua, bahwa cacat tersebut telah menyebabkan atau turut menyebabkan kerugian/kecelakaan; ketiga, adanya kerugian. tanggung jawab produsen (product liability) yang menganut prinsip tanggung jawab mutlak (stict liability) dalam mengantisipasi kecenderungan dunia dewasa ini yang lebih menaruh perhatian pada perlindungan konsumen dari kerugian yang diderita akibat produk yang cacat. berlakunya prinsip strict liability dalam hukum tentang product liability tidak berarti pihak produsen tidak mendapat perlindungan. Pihak produsen juga dapat mengasuransikan tanggung jawabnya sehingga secara ekonomis ia tidak mengalami kerugian yang berarti.

Penerapan Prinsip Tanggung Jawab Mutlak dalam Transaksi $E$ Commerce. Di dalam transaksi di dunia maya (e-commerce, )tanggung jawab produk sangat penting dan berguna untuk melindungi hak-hak konsumen. Hak untuk mendapatkan kompensasi, ganti rugi, dan/atau penggantian atas ganti rugi akibat penggunaan, pemakaian, dan pemanfaatan barang dan/atau jasa yang diperdagangkan menjadi tanggung jawab dari pelaku usaha. ${ }^{8}$ Sistem tanggung jawab produk bagi konsumen dalam transaksi e-commerce di berbagai Negara sudah menerapkan Prinsip tanggung jawab mutlak, yang semula dikembangkan melalui pengadilan, kemudian mendapat pengakuan yang kuat setelah dituangkan dalam hukum tertulis. Di Amerika Serikat dalam tanggung jawab produk transaksi e-commerce menggunakan tanggung jawab mutlak. dalam hukum tertulis dituangkan dalam Pasal 402 A. Di Uni Eropa tanggungjawab produk yang digunakan pada masyarakat UE puncak pembentukan standar tanggung jawab produk adalah ketentuan yang disebut Council Directive 85/374/EEC pada tanggal 25 Juli 1985. Hukum perlindungan konsumen di India sudah menerapkan prinsip tanggung jawab mutlak. Dalam transaksi e-commerce konsumen harus berhati-hati terhadap klausul-klausul tertentu dalam kontrak pelaku usaha dan konsumen, yang secara luas digunakan saat ini oleh pelaku usaha.

\footnotetext{
${ }^{8}$ Elia Wuria Dewi. Hukum Perlindungan Konsumen (Yogyakarta: Graha Ilmu, 2015).
} 
Fitriah; Tanggung Jawab Produk Dalam Transaksi E-Commerce, Halaman 118-125

Perlindungan hukum bagi

konsumen transaksi e-commerce di dunia maya, mengalami perubahan dari hukum yang berkarakteristik represif, dalam bentuk prinsip tanggung jawab berdasarkan kesalahan ke prinsip tanggung jawab yang berpihak atau responsif terhadap kepentingan konsumen dalam bentuk tanggung jawab mutlak. Karena lebih memberikan perlindungan hukum bagi konsumen dalam bertransaksi. mendapatkan informasi yang benar dan jujur adalah hak konsumen yang wajib diperhatikan oleh para pihak pelaku usaha dimanapun. ${ }^{9}$ Dengan diberlakukannya prinsip tanggung jawab mutlak diharapkan para pelaku usaha menyadari betapa pentingnya menjaga kualitas produk-produk yang dihasilkannya.

\section{KESIMPULAN}

Tanggung Jawab Produk (Product Liability), merupakan tanggung jawab perdata dari pelaku usaha atas kerugian yang dialami konsumen. Pentingnya hukum tentang tanggung jawab produsen (product liability) yang menganut prinsip

9 Janus Sidabalok, Hukum Perlindungan Konsumen di Indonesia (Bandung: PT. Citra Aditya Bakti, 2006). tanggung jawab mutlak (stict liability) dalam mengantisipasi kecenderungan dunia global menaruh perhatian pada perlindungan konsumen yang mempunyai posisi yang lemah, khususnya konsumen dalam transaksi e-commerce. Dalam transaksi $e$ commerce penerapan tanggung jawab mutlak dapat lebih memberikan perlindungan hukum bagi konsumen dalam bertransaksi.

\section{DAFTAR PUSTAKA}

Agus Raharjo. Cybercrime: Pemahaman dan Upaya Pencegahan Kejahatan Berteknologi. Bandung: PT. Citra Aditya Bakti, 2002.

Ardiana Hidayah. "Konsp Pembangunan Hukum ECommerce."

http://jurnal.unpal.ac.id/index.ph p/solusi/article/view/168/134,

Solusi, Volume 17 Nomor 2. Bulan Mei (2019): 107

Elia Wuria Dewi. Hukum Perlindungan Konsumen. Yogyakarta: Graha Ilmu, 2015.

Husni Ayawali, Neni Sri Imaniyati (ed). Hukum Perlindungan Konsumen. Bandung: Mandar Maju, 2000.

Janus Sidabalok, Hukum Perlindungan Konsumen di Indonesia. Bandung: PT. Citra Aditya Bakti, 2006.

Jhon M Echols dan Hasan Sadly. Kamus Inggris-Indonesia. Jakarta: Balai Pustaka, 1995. 
Fitriah; Tanggung Jawab Produk Dalam Transaksi E-Commerce, Halaman 118-125

Tami Rusli. "Tanggung Jawab Produk

Dalam Hukum Perlindungan

Konsumen."

https://media.neliti.com/media/pu

blications/26769-ID-tanggung-

jawab-produk-dalam-hukum-

perlindungan-konsumen.pdf,

Jurnal Pranata Hokum, Volume

7 Nomor 1 Januari 2012.

Soemardjono Brodjo Soedjon. "Hukum

Perlindungan Konsumen dalam

Transaksi Konsumen di Dunia

Maya tentang Tanggung Jawab

Produk."https://media.neliti.com/ media/publications/220778-

hukum-perlindungan-konsumen-

dalam-transa.pdf

Zulham. Hukum Perlindungan

Konsumen. Jakarta: Kencana

Penada Media Group.. 